Volume 5 Issue 2, June 2018

\title{
The Implementation Of Boundary Marks Obligations For Land Ownership Rights Based On Pp No 24 Of 1997 As One Of The Facilities Of Legal Certainty Provision In Kudus
}

\author{
Lucky Wahyu Andriyanto ${ }^{1}$, Kustriyo ${ }^{2}$ and Amin Purnawan ${ }^{3}$
}

\begin{abstract}
In order to ensure certainty of land rights and certainty, the UUPA has outlined the necessity to carry out land registration throughout Indonesia. One of the land registration activities is the land measurement with the obligation to install boundary line markers for land owners, in order to avoid land disputes in the later days. The approach method was done by social jurisdiction by using primary data and secondary data. The data were gained through interview and library method, then they were analyzed qualitatively. The results of the discussion indicate that (1) the implementation of the obligation to install the land boundary line is done by the holder of the land right with the approval of the neighbors land holder who is bordered by the village apparatus or device and the legal consequences can cause the land dispute (2) provide legal certainty to the holder of the land rights (3) The obstacles faced are the absence of the holder of the land right and the need for the presence of the right holder in accordance with the timing of the installation of the land boundary.

Keywords: Land Registration; Legal Certainty; Installation of Land Border Marks
\end{abstract}

\section{Introduction}

The problem of land has long been a complicated and complex legal issue and has broad dimensions in both developed and developing countries. Thus, it is not easy to solve it quickly. ${ }^{4}$ Although the ownership of land has been regulated in such a way as in Government Regulation No. 24 of 1997 on Land Registration, but still there are problems that occur in the field such as the overlapping of land boundaries due to unclear boundaries of a plot of land caused by the land owner does not maintain the Land Border Marks. Furthermore, the owner of the land as the holder of the land certificate does not know their own land border since there is no Land Border Marks or the line is long gone. Similarly, in the case of ownership of land, for example, on a piece of land that has been controlled by the legal subject for many years and has been equipped with a certificate, but there is someone who claim that land. These such problems often occur in various regions in Indonesia.

With regard to land registration activities, it is done to ensure legal certainty on subjects and objects of land rights. One of the activities is to carry out measurement. The measurement problems for land registration purposes are things that should not be ignored and it is an important part that needs to get serious and careful attention. The measurement itself is a major undertaking, requiring considerable cost and extra effort to make measurements and to be conducted from village to village in areas designated by the Minister of Agrarian Affairs, in this case is the Land Office.

The landlord or owner of the land rights must perform the obligation to install or maintain

\footnotetext{
1 Student of Master Program (S2) of Notaries Faculty of Law Universitas Islam Sultan Agung email :luckywahyu61@gmail.com

2 Students of Master of Law, Faculty of Law, Universitas Islam Sultan Agung email Koestriyo81@gmail.com

${ }^{3}$ Lecturer of Faculty of Law UNISSULA

${ }^{4}$ Irawan Soerodjo 2002 Kepastian Hukum Hak atas Tanah di Indonesia Penerbit Arkola

Surabaya p.25.
} 
a boundary line mark (sporadic registration), as defined in article 17 of Government Regulation No. 24/1997. The obligation to install or maintain existing Land Border Marks is intended to avoid the occurrence disputes over land boundaries or overlapping.

The problem formulation in this research are: How is the obligation of execution of installation of Land Border Marks based on PP. 24 of 1997 as one means of providing legal certainty in the Land Office of Kudus Regency and what it the legal consequences? How is the responsibility of National Land Agency on the implementation of the obligation to install the Land Border Marks for the land right owner based on Government Regulation no. 24 of 1997 which provides assurance of legal certainty to the holder of the right to land?; What are the obstacles faced in the implementation of the installation of Land Border Marks based on PP no. 24 of 1997 as one means of providing legal certainty in the Land Office of Kudus Regency and how to overcome it?

\section{Research Methods}

The approach method used in this study was the empirical juridical approach. The specification of this research was descriptive analytical. In the method of determining the sample used is Purposive Sampling Data required in this discussion were primary and secondary data. The data analysis technique used in this study is descriptive analytical.

\section{RESULT AND DISCUSSION}

\subsection{The Implementation Of Boundary Marks Obligations For Land Ownership Rights Based On PP No. 24 Of 1997 As One Of The Facilities Of Legal Certainty Provision In Kudus}

Legal certainty to the owner or who controls the land to conduct land registration is based on PP. 24 of 1997, this is evident in the sporadic systematic registration of land and systematic system. Sporadic registration is kind of method that the land owners who are active to register their land. On the other hand, systematic land registration is done massively with government program.

The first land registration process is a physical activity for obtaining data on its location, its borders, its extent and the buildings contained thereon. The determination of borders and the provision of clear boundary markings is based on the appointment by the holder of land rights with the consent of the neighbor landowners. Furthermore, the measurements are followed by the calculation of the area and the making of the map of the land. Finally the result is published into a measurement letters. ${ }^{5}$

Determination of the boundary of the land is regulated in Article 19 PMNA / KBPN 3/1997, namely;

(1) For the purposes of stipulation of the boundary of the land land as referred to in Article 18 PP 24/1997 are;

a. The concerned applicant make registration sporadically, or;

b. Holders of land rights that have not been registered but there is no measurement/picture of the situation or the measurement/picture letter is no longer appropriate with the actual situation, and the party who controls the land in question, in the registration of the land systematically, shall be required to indicate the boundaries of the land concerned, and if there is agreement on such borders with the right holders of the adjacent land, put up their border marks.

In article 22 PMNA/KBPN 3/1997 also mentioned that the land can use boundary marks in

\footnotetext{
${ }^{5}$ Boedi Harsono 2003 Hukum Agraria Indonesia Sejarah pembentukan Undang-Undang Pokok Agraria Isi dan Pelaksanaannya Djambatan Jakarta p. 54
} 
the form of metal pipes paralon, iron /wood teak, monument of brick/concrete.

The placement of border markers including their maintenance shall be carried out by the rights holder concerned, this is provided for in Article 17 and Article 18 of Government Regulation No. 24 of 1997.

The form of land boundary marks shall be determined in the Regulation of the Minister of Agrarian Affairs/Head of the National Land Agency No. 3 of 1997. The form of land boundary marks, in principle, is divided into two, namely for the land area of less than 10 ha and the land area of more than 10 ha. Land borders can be iron pipes or iron rods, pipes filled with pebbles and cement, strong wood, concrete, stone or red/brick pillars of a certain size.

Installation of boundary markers for land rights owners should be witnessed by village officials or officials who know or have data about land ownership and the boundaries of the land concerned. Similarly, land that has not been registered or still in the form of letter $C$ or letter $D$, only village officials who know the beginning of ownership of the land. In determining of the boundaries of land that have not been registered, it is necessary to make a statement signed by the legitimate land owner and the landowner entirely adjoining and the signature of the Village Head or Village Head. The Land Office also provides a list of Issues 201, the written evidence is a condition of the landowner to apply for the measurement or determination of the boundary mark.

The obligation to implement the installation of land borders by the owner of the land concerned is other than regulated in Government Regulation No. 24/1997, also described in the Regulation of the Minister of Agrarian Affairs/Head of the National Land Agency Number 3 of 1997 concerning Provisions on the Implementation of Government Regulation No. 24/1997 in Article 20 - Article 23.

Determination of physical data or the determination of land ownership boundary shall be regulated by Article 17 of Government Regulation No. 24 of 1997 based on the agreement of the parties. If there is no agreement, a provisional boundary shall be stipulated in Article 19 of Government Regulation Number 24 of 1997. Data on the size of the location of the boundary of the lands shall be recorded in the field in the Measurement Image. Furthermore, it shall be kept in the Land Office for all time as long as the land is still present. In the future, the data must be used for the reconstruction of the plot boundary location when the map lost. Landowners and adjoining landowners who may be present witness the measurements signing the Measure Draw by making a statement that the border marks at the time of measurement or boundary setting do not change as the agreed Statement Letter. If the implementation of the obligation to install land boundary markers is not in accordance with the applicable rules, for example not in accordance with the use of materials, the form of the boundary and the size of the land boundary marks, it will cause weak evidence or become the cause of the law of dispute in the future. ${ }^{6}$

As a result of the law on the implementation of the installation of land boundary marks based on Government Regulation No. 24 of 1997 is as one of the means of providing legal certainty in the Land Office of Kudus Regency. If the determination of the land boundary mark by the owners either unregistered or already registered, but there is no letter or letters not in accordance with the conditions in the field. It is better for the applicant to get agreement upon by the holder or owner of the adjacent land rights. However, if the holder of the adjacent land rights does not agree to the designated land mark, in accordance with the evidence of existing rights, the process of measurement to place the land boundary marks becomes complicated. The solution is all parties have to make a consensus effort first, if there is no result in agreement between the adjacent parties, the measuring officer shall not determine the boundary of the land based on the applicant want. This issue

\footnotetext{
${ }^{6}$ Interviewed with The Head Of Infrastructure Section Land Agency Kudus 5 April 2018
} 
should be submitted to the court to decide and set borders of ownership, so that the legal certainty is guaranteed. ${ }^{7}$ This is to avoid the occurrence of a land dispute resulting from the boundary and the incorrect plot of land or in the process of measuring adjacent land object to the determination of the boundary and the measurement of the plot of land will be resolved peacefully.

Another legal consequence if the adjacent land owner do not submit any lawsuit to the land border marks up to 5 years, the new certificate position of the non-marking land rights will be weak for verification in the boundary disputes lawsuit. Further, the owner cannot submit the dispute to the court. This can be indicated in Article 32 paragraph (2) of Government Regulation No. 24 of 1997.

\subsection{The Responsibility of National Land Agency against the Implementation of Land Boundary Marks Installation for the Land Owner Based on Government Regulation No. 24 of 1997 which Provides A Guarantee Of Legal Certainty To The Holder Of Land Rights}

In handling such land disputes, the BPN (National Land Agency) shall make various efforts to ensure the certainty of one's right to ownership of a plot of land. Normatively, BPN is the only institution in Indonesia that is given the authority to carry out the mandate to manage the land sector. It is in accordance with Presidential Decree No. 10 of 2006 on the National Land Agency which states that BPN performs its tasks in the field of national and regional sectorial land. The basis for the establishment of BPN is Presidential Decree No. 26 of 1988. As an operational guide of BPN, the chairman of this institution then issued Decree No. 11 / KBPN / 1988 jo Decision of the Head of BPN No. 1 of 1989 on Organization and Administration of BPN in Province and Regency/Municipality. Even through the same process, the government has also strengthened the role and position of BPN by forming Deputy $\mathrm{V}$ which specifically examines and resolves land disputes and conflicts.

In practice, the settlement of land disputes is not only done by the National Land Agency but can also be resolved by the General Courts and State Administration Courts. If the general court is concerned with matters of civil and criminal matters in land disputes, it is different from the state administrative courts that resolve land disputes in relation to the decree issued by the National Land Agency or other land-related officials.

\subsection{Obstacles Encountered In The Implementation Of The Installation Of Land Boundary Marks Based On PP No. 24 of 1997 As One Of Providing Legal Certainty In The Kudus And How To Overcome It}

Land dispute that occurred, based on interviews explained by the informant that the land conflict is a broad dimension, either horizontal conflict or vertical conflict. The most vertical conflict is between the community and the government or state-owned enterprises and private-owned companies. Meanwhile, the dispute between the communities itself is in terms of land ownership border. Where each party considers to have the most correct information. The cause of the land dispute is basically the economic value of the land "high enough" and the land is a symbol of existence and social status in the middle of society resulting in the occurrence of vertical and horizontal land conflicts. The meaning and value of such a strategic and privileged land encourage everyone to own, maintain and care for the land properly. Specifically, land disputes that occur in some

\footnotetext{
${ }^{7}$ Abdul Rahim Lubis dan Yamin 2010 Lubis Hukum Pendaftaran Tanah Mandar Maju Bandung p.137
} 
areas in Kudus Regency, among others, the parties concerned are not present in the determination of the boundary. Neither the applicant nor the adjoining landowner cannot come at the time of setting the boundary of the land, this impedes in the measurement and to slow the completion of land registration. The absence of the adjacent parties may be due to a number of reasons, among others, the party adjacent to the time of border determination is outside the city even the family or the representative cannot follow the determination of the border. However, the absence of the parties concerned does not directly cover the process of measurement, the BPN (National Land Agency) will only invite the local government (Village or District Party) to present witness the measurement process as well as a witness who validates that the land is true ownership of the applicant and so does the position adjacent boundary.

There are many lands that do not have boundary, it is due to the lack of awareness of the community to maintain the boundary marks or the plot of land. It has caused the measurement officer difficulty, because the land boundary is not clear. Furthermore, this condition makes it difficult in the measurement and mapping. In addition, the boundary marks are not well maintained may also result in the recognition of the other party adjacent to the area of land owned by it then resulting in a dispute in the future.

Constraints often encountered in the implementation of land measurement in general is difficult to bring landowners who are in conflict or adjacent to the object of land to be appealed for their rights. Especially is in the first land registration activity held sporadically (eg in PRONA activities). Where the applicant and the adjacent landowner is difficult to present at the time of field measurement and only delegates all matters to the village apparatus as the implementing committee at the village level. In addition, sometimes the applicant does not know the exact boundary of the land, so the implementation of the veldwerk signing or the measurement drawing (GU) of the land is difficult to obtain the exact data and often done incorrectly. These matters will certainly affect the reduction of the legal certainty substance of the object of the rights in question causing the uncertainty of the location and boundaries of the plot of land and the potential for the emergence of boundary disputes. Therefore, the installation of the boundary mark is an absolute levy prior to the measurement of the ground plane. It is an order of law as mentioned in Article 17 of Government Regulation no. 24 of 1997.

\section{CONCLUSION}

- Implementation of the obligation to install land boundary marks shall be carried out at the Land Office in Kudus. Conducted by the holder of land rights with the approval of the land rights holders adjacent to the village apparatus and the legal consequences. If it does not perform the boundary installation obligation may cause land disputes of either the holder of the land rights concerned with the adjacent land rights holder, causing the dispute of heirs with the holder of the adjacent land rights, causing confusion in the sale and purchase of land.

- Responsibility of BPN (National Land Agency) on the implementation of the obligation to install border marks for land rights owners. Government Regulation No. 24 of 1997 provides assurance of legal certainty to the holder of land rights that is the measuring officer so that the BPN will issue data in the field and issue the certificate.

- Obstacles faced in the implementation of the installation of land boundary marks based on PP No. 24 of 1997 as one of the means of providing legal certainty in the Land Office of Kudus Regency is the absence of the land rights holders, the need for the presence of the right holder of the land according to the time of the installation of land boundaries 


\section{Referernces}

[1] Abdul Rahim Lubis dan Yamin 2010 Lubis Hukum Pendaftaran Tanah Mandar Maju Bandung.

[2] Boedi Harsono 2003 Hukum Agraria Indonesia Sejarah pembentukan UndangUndang Pokok Agraria Isi dan Pelaksanaannya Djambatan Jakarta.

[3] Irawan Soerodjo 2002 Kepastian Hukum Hak atas Tanah di Indonesia Penerbit Arkola Surabaya.

[4] Interviewed with The Head Of Infrastructure Section Land Agency Kudus 5 April 2018 